\title{
WATER QUALITY ASSESSMENT OF DUG WELL WATER AND ITS ADJOINING BURIGANGA RIVER REACH IN THE OLD DHAKA OF BANGLADESH
}

\author{
SHOVON BARUA ${ }^{1}$ AND M. SAIFUL ISLAM ${ }^{2}$ \\ 'Department of Geology, Kansas State University, Manhattan, KS-66506, USA \\ ${ }^{2}$ Department of Geology, University of Dhaka, Dhaka-1000, Bangladesh
}

\begin{abstract}
Thirty six dug well water samples from different houses along three transects and four Buriganga river water samples from four different Ghats (boat terminals) of the Old Dhaka of Bangladesh were collected during dry and wet periods for water quality assessment. The depth of these dug wells varies from 3.4 to $16 \mathrm{~m}$ with an average depth of $10 \mathrm{~m}$ with diurnal variations. The hydrochemical classification shows that the dug well and Buriganga river water samples are $\mathrm{Ca}-\mathrm{HCO}_{3}$ type. More than $50 \%$ dug well water samples were contaminated as concentration levels of $\mathrm{Ca}, \mathrm{K}$ and $\mathrm{Fe}$ in both periods were high whereas over $25 \%$ Buriganga river water samples were tainted as concentration levels of $\mathrm{Ca}, \mathrm{Mg}, \mathrm{Fe}$ and $\mathrm{Mn}$ in dry season exceeded the drinking water quality standard limits of World Health Organization (WHO), Department of Environment (DOE) and United States Environmental Protection Agency (USEPA). If the dug well water is protected from contamination, the shallow groundwater in this part of Dhaka city should be an alternative perennial source of water especially during the dry season when water scarcity looms large.
\end{abstract}

Keywords: Dug well, Buriganga river, Physical and chemical parameters, Water quality

\section{Introduction}

Groundwater perhaps constitutes the largest source of dug well. It is located below the soil surface and largely contained in interstices of bedrocks, sands, gravels and other interspaces through which precipitation infiltrates and percolates into the underground aquifers due to gravity. Dug wells became relatively safer source of water. It is not evident when first dug well was sunk in Dhaka. However, there is reference to a dug well sunk by Guru Nanak who visited Dhaka in the 16th Century on his way from Dhibru (Assam) to Jaganath Puri (Orissa). It is learnt that Guru Nanak's well now lies at House No. 278, Road No. 26, Dhanmandi residential area. The allotee of this plot of land constructed a building there in 1968 (Ahmed et al 2011). The dug wells might have provided water for Dhaka dwellers for long time. Taylor (1840) mentioned about the need for artesian wells in Dhaka to prevent cholera epidemic. However, the quality of water was not very good as evident from the report of the Civil Surgeon in 1869. The report stated that water of all dug wells of the city was contaminated; water from the rivers and canals was full of pathogens. There are mentions of dug wells even in 1968 as

\footnotetext{
${ }^{1}$ Corresponding author. E-mail: barua.shovon26@gmail.com
} 
a source of drinking water for Dhaka dwellers (Khan and Stockard 1968). Groundwater utilisation in the Indian subcontinent dates back to prehistoric time as evidenced by the presence of water wells in Harappa and Mohenjo-Daro. D'Souza (2006) notes the existence of dug well and step wells in the region long before the British role started (Ahmed et al 2011). Still today there are a few dug wells found in the city, shown in Fig. 1, some of them are being used. Most of the existing dug wells are found in the areas where there is an alluvial cover on top of the Madhupur Clay (Ahmed et al 2011). People around Buriganga river bank in older part of Dhaka city have been utilizing dug well water since British period for their daily household cleansing and drinking purposes without the knowledge of water quality. Water scarcity is one major issue in the study area. Therefore, most of the inhabitants of that region depend on alternative water sources. The objective of the study is to understand the quality of the existing and using dug well water as well as adjoining Buriganga river reach water for investigating whether both sources do provide safe water or not.

\section{Materials and Methods}

Study Area: Old Dhaka is located in the southern part of the Dhaka city and lies between $23^{\circ} 41^{\prime} 0^{\prime \prime} \mathrm{N}$ and $23^{\circ} 43^{\prime} 15^{\prime \prime} \mathrm{N}$ latitude, and $90^{\circ} 24^{\prime} 0^{\prime \prime} \mathrm{E}$ and $90^{\circ} 26^{\prime} 0^{\prime \prime} \mathrm{E}$ longitude. It covers an area of $7.9 \mathrm{~km}^{2}$ and lies on the northern bank of Buriganga river. The river commonly shows dendritic pattern and only the western part of river system shows trellis pattern. At the land surface, Pleistocene alluvium occupies the dissected uplands and alluvium of recent river-borne deposits covers the low-lying flood plains. Topographically Old Dhaka is almost flat with many depressions and physiographically it is located in the southern half of the Madhupur Tract and Floodplain area with southern river system. The elevation of the area ranges from 10 to $17 \mathrm{~m}$ but is generally around $14 \mathrm{~m}$ above MSL. The study area belongs to Bengal Foredeep and geologically, it is situated in the Pleistocene uplifted block (Madhupur Tract) within the passive margin surrounded by subsiding floodplains (Miah and Bazlee 1968) bounded on the west by a series of NW-SE trending en-echelon faults including the Dhamrai, Maijail and Kaliakoir ones. The region is covered by gray floodplain and non-Cretaceous floodplain soils. Stratigraphically, Old Dhaka is characterized by an unconsolidated sequence of fluvio-deltaic deposits of many hundreds of meters usually composed of gravels, sands, silts and clays of PlioPleistocene age (Monsur 1995).

Sample Collection, Processing and Analyses: Reconnaissance and field survey suggest that there were as many as $120-150$ dug wells during the British rule. Now-a-days the figure has been reduced to 50-60. Among them thirty six dug well water samples arbitrarily from different old houses and four Buriganga river water samples from four different boat terminals were collected during both dry (April 2010) and wet (September 
2010) periods along three transects with some of them are close by the river and some being are far away from the river (Fig. 2).

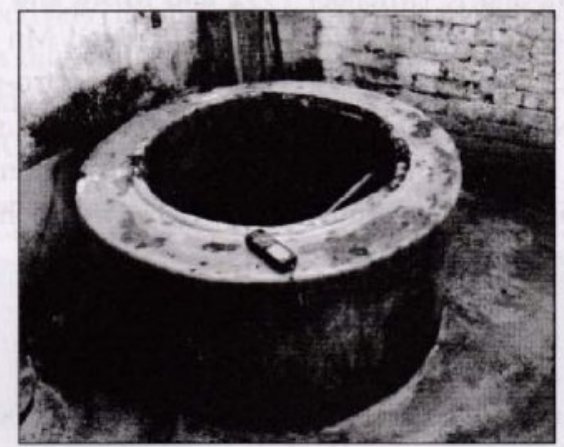

Fig. 1. A dug well in the study area.

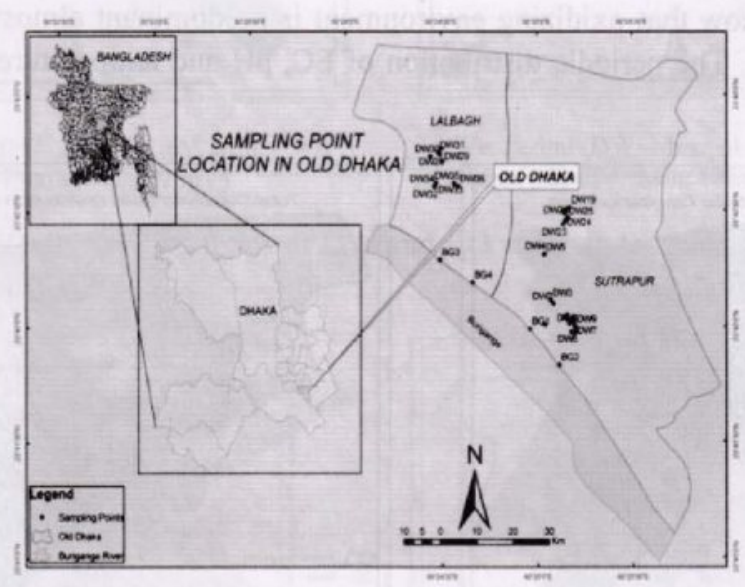

Fig. 2. Map of the study area showing the sampling locations.

Two $125 \mathrm{~mL}$ PVC bottles were used for sampling. During sampling $0.45 \mu \mathrm{m}$ membrane filters were used to filter dug well and Buriganga river water samples in order to remove colloidal materials and other unwanted particles from the water samples. One bottle of sample was acidified using concentrated $\mathrm{HNO}_{3}$ to lower the $\mathrm{pH}$ value to $<3$ to avoid precipitation of the dissolved constituents from the samples. Sampling process was started by rinsing the sample bottles three times with the filtered water; then two-third of the $125 \mathrm{~mL}$ sample bottle was filled with the filtered water and it was acidified with concentrated $\mathrm{HNO}_{3}$ and then the rest of the bottle was filled up leaving no empty space. Physico-chemical parameters like $\mathrm{pH}, \mathrm{Eh}, \mathrm{EC}$, TDS and temperature were measured in 
the field. Different methods were applied for determining the concentration of different chemical constituents of the sample waters; flame photometer (Jenway PFP-7) wavelength $769 \mathrm{~nm}$ for $\mathrm{Na}$ and $\mathrm{K}$ (Michael 1992 and Misra and Ahmed 1987); atomic absorption spectrometer (GBC SensAA) for $\mathrm{Ca}, \mathrm{Mg}, \mathrm{Fe}$ and $\mathrm{Mn}$ (Page 1982); titration method for $\mathrm{HCO}_{3}$ and $\mathrm{Cl}$ (Jackson 1967); UV-Visible spectro-photometer (T60 PG) wavelength $410 \mathrm{~nm}$ for $\mathrm{NO}_{3}$ and $\mathrm{SO}_{4}$ (Page 1982). ArcGIS 9.2 software was used for preparing maps such as location map and spatial distribution map. RockWorks 15 software was employed for piper diagram which describes hydrochemical facies analyses (Piper 1953).

\section{Results and Discussion}

Physical Parameters: During dry period the total dissolved solids (TDS) of dug well water varied from 301 to $733 \mathrm{mg} / \mathrm{L}$ whereas the same during wet period ranged from 256 to $641 \mathrm{mg} / \mathrm{L}$. The TDS of Buriganga river water is very low compared to that of dug well water in both dry and wet periods (Fig. 3). Spatial distribution maps of Eh both for dry and wet periods show that oxidizing environment is predominant almost throughout the study area (Fig. 4). The periodic distribution of EC, $\mathrm{pH}$ and temperature has been given in Table 1.

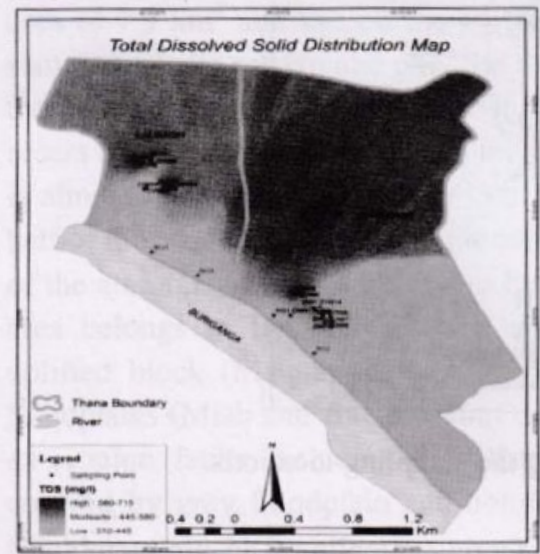

(a) Dry Period (DW- Max. 733 mg/L, Min. 301 $\mathrm{mg} / \mathrm{L}$; BG- Max. $371 \mathrm{mg} / \mathrm{L}$, Min. $348 \mathrm{mg} / \mathrm{L}$ )

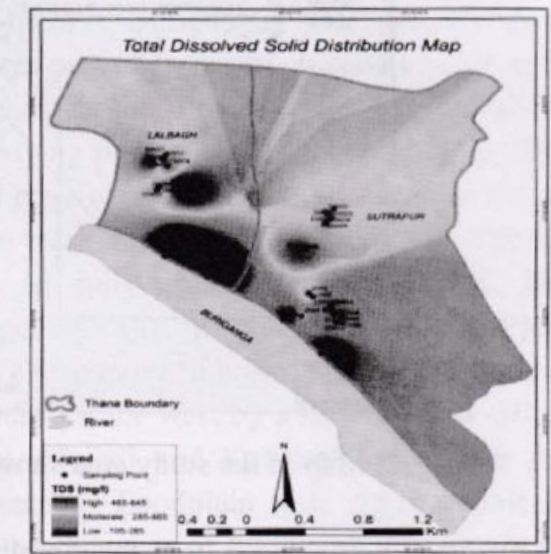

(b) Wet Period (DW-Max. $641 \mathrm{mg} / \mathrm{L}$, Min. 256 $\mathrm{mg} / \mathrm{L}$; BG- Max. $209 \mathrm{mg} / \mathrm{L}$, Min. $105.2 \mathrm{mg} / \mathrm{L}$ )

Fig. 3. TDS ( $\mathrm{mg} / \mathrm{L}$ ) distribution maps of dug well (DW) and Buriganga river (BG) water in the study area during dry (a) and wet (b) period.

Chemical Parameters: Anions: The $\mathrm{HCO}_{3}$ ion concentration of dug well and Buriganga river water during dry period ranged from 213.5 to $518.5 \mathrm{mg} / \mathrm{L}$ and 274.5 to $449.9 \mathrm{mg} / \mathrm{L}$, while the same varied from 228.8 to $1052.3 \mathrm{mg} / \mathrm{L}$ and 114.4 to $137.3 \mathrm{mg} / \mathrm{L}$ during wet period, respectively (Fig. 5). This means that $\mathrm{HCO}_{3}$ concentration in dug well 
water increased but that in Buriganga river water decreased during wet period. The $\mathrm{NO}_{3}$ ion concentrations of dug well and Buriganga river water ranged from 0 to $0.8 \mathrm{mg} / \mathrm{L}$ and 0 to $0.3 \mathrm{mg} / \mathrm{L}$, respectively during dry period (Fig. 6). During wet period the $\mathrm{NO}_{3}$ concentrations of both dug well and Buriganga river water had declined and the ranges were 0 to $0.3 \mathrm{mg} / \mathrm{L}$ and 0 to $0.1 \mathrm{mg} / \mathrm{L}$, respectively (Fig. $4 \mathrm{~b}$ ). The periodic distribution of other anions $\left(\mathrm{Cl}\right.$ and $\left.\mathrm{SO}_{4}\right)$ has been given in Table 2 .

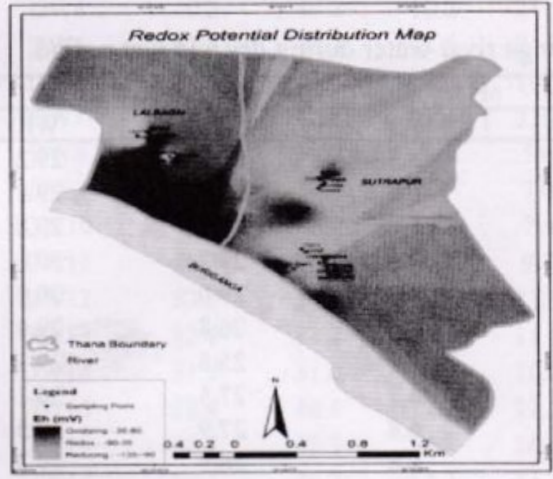

(a) Dry Period (DW- Max. $86 \mathrm{mV}$, Min. -140 $\mathrm{mV}$; BG- Max. $75 \mathrm{mV}$, Min. $57 \mathrm{mV}$ )

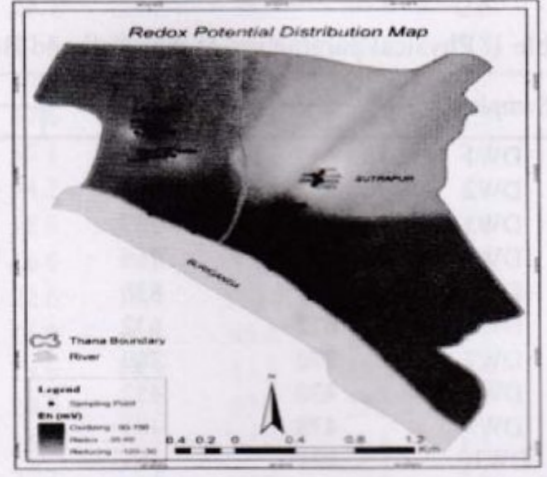

(b) Wet Period (DW- Max. $141 \mathrm{mV}$, Min, $-125 \mathrm{mV}$; BG- Max. $123 \mathrm{mV}$, Min. $48 \mathrm{mV}$ )

Fig. 4. Eh (mV) distribution maps of DW and BG water in the study area during dry (a) and wet (b) period.

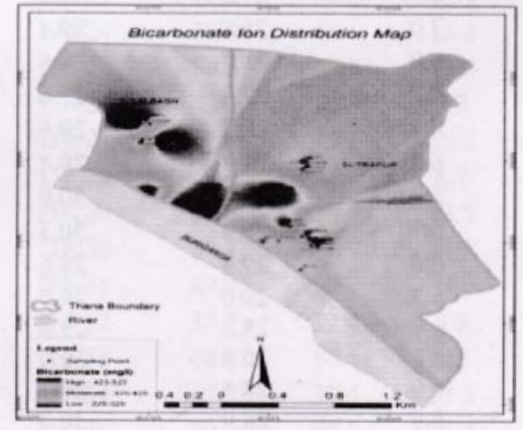

(a) Dry Period (DW- Max. $518.5 \mathrm{mg} / \mathrm{L}$, Min $213.5 \mathrm{mg} / \mathrm{L}$; BG- Max. $449.9 \mathrm{mg} / \mathrm{L}$, Min. $274.5 \mathrm{mg} / \mathrm{L}$ )

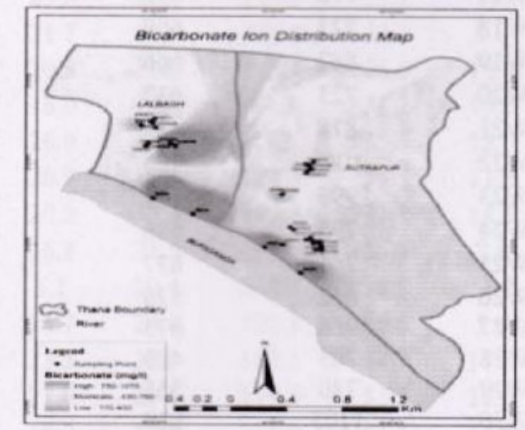

(b) Wet Period (DW- BG- Max. $1052.2 \mathrm{mg} / \mathrm{L}$, Min. 228.8 $\mathrm{mg} / \mathrm{L}$; BG- Max. $137.3 \mathrm{mg} / \mathrm{L}$, Min. $114.4 \mathrm{mg} / \mathrm{L}$ )

Fig. 5. $\mathrm{HCO}_{3}$ ion concentration distribution maps of $\mathrm{DW}$ and $\mathrm{BG}$ water in the study area during dry (a) and wet (b) period.

Cations: The $\mathrm{Ca}$ ion concentration of dug well and Buriganga river water in the study area ranged from 23 to $251.1 \mathrm{mg} / \mathrm{L}$ and 47.6 to $188.5 \mathrm{mg} / \mathrm{L}$ in dry period, whereas the concentrations had declined in wet period and it varied from 63.1 to $151.8 \mathrm{mg} / \mathrm{L}$ and 30.1 
to $38.6 \mathrm{mg} / \mathrm{L}$, respectively (Fig. 7). During dry period the range of concentration of $\mathrm{Fe}$ ion in dug well and Buriganga river water was 6.4 and $0.2 \mathrm{mg} / \mathrm{L}$, and 0.5 and $5.0 \mathrm{mg} / \mathrm{L}$, respectively; on the other hand, the concentrations had decreased in wet period and the range was from 4.6 to $0.1 \mathrm{mg} / \mathrm{L}$ and 0.5 to $1.0 \mathrm{mg} / \mathrm{L}$, respectively (Fig. 8). During dry period the $\mathrm{Mn}$ ion concentrations of dug well and Buriganga river water ranged from 0.1 to $2.4 \mathrm{mg} / \mathrm{L}$ and 0.3 to $2.1 \mathrm{mg} / \mathrm{L}$ but during wet period it ranged from 0.1 to $2.0 \mathrm{mg} / \mathrm{L}$ and 0.1 to $0.6 \mathrm{mg} / \mathrm{L}$, respectively (Fig. 9). The periodic distribution of other cations $(\mathrm{Na}, \mathrm{K}$ and $\mathrm{Mg}$ ) has been presented in Table 2 .

Table 1. Physical parameters of dug well and Buriganga river water during dry and wet period.

\begin{tabular}{|c|c|c|c|c|c|c|}
\hline \multirow{2}{*}{ Sample ID } & \multicolumn{2}{|c|}{$\mathrm{EC}(\mu \mathrm{S} / \mathrm{cm})$} & \multicolumn{2}{|c|}{$\mathrm{pH}$} & \multicolumn{2}{|c|}{$\operatorname{Temp}\left({ }^{\circ} \mathrm{C}\right)$} \\
\hline & DP & WP & DP & WP & DP & WP \\
\hline DW1 & 649 & 692 & 6.6 & 6.5 & 28.7 & 29.2 \\
\hline DW2 & 637 & 688 & 6.9 & 6.8 & 28.4 & 29.8 \\
\hline DW3 & 1017 & 759 & 6.9 & 6.8 & 28.4 & 29.8 \\
\hline DW4 & 743 & 765 & 6.9 & 6.8 & 27.7 & 30.6 \\
\hline DW5 & 907 & 836 & 6.9 & 6.8 & 29.0 & 30.0 \\
\hline DW6 & 672 & 672 & 6.9 & 7.0 & 26.8 & 29.4 \\
\hline DW7 & 770 & 789 & 6.9 & 6.9 & 25.5 & 29.1 \\
\hline DW8 & 430 & 452 & 6.9 & 6.7 & 27.5 & 30.1 \\
\hline Dw9 & 478 & 484 & 6.9 & 6.8 & 27.9 & 30.5 \\
\hline DW10 & 721 & 463 & 6.9 & 6.8 & 26.9 & 29.3 \\
\hline DW11 & 643 & 567 & 6.8 & 6.7 & 28.1 & 30.6 \\
\hline DW12 & 924 & 556 & 6.9 & 6.8 & 26.2 & 29.7 \\
\hline DW13 & 483 & 499 & 6.9 & 6.8 & 27.1 & 28.9 \\
\hline DW14 & 466 & 502 & 6.9 & 6.7 & 28.1 & 28.7 \\
\hline DW15 & 835 & 628 & 6.8 & 6.7 & 25.9 & 29.1 \\
\hline DW16 & 558 & 652 & 6.9 & 7.1 & 27.4 & 30.0 \\
\hline DW17 & 778 & 629 & 6.8 & 6.7 & 27.2 & 30.0 \\
\hline DW18 & 723 & 609 & 6.9 & 7.0 & 26.8 & 29.4 \\
\hline DW19 & 862 & 666 & 6.9 & 6.9 & 28.7 & 29.6 \\
\hline DW20 & 725 & 637 & 6.7 & 6.7 & 27.4 & 29.6 \\
\hline DW21 & 878 & 487 & 6.7 & 6.7 & 28.2 & 29.6 \\
\hline DW22 & 1048 & 796 & 6.8 & 6.8 & 27.7 & 29.4 \\
\hline DW23 & 996 & 791 & 6.9 & 6.9 & 27.8 & 30.9 \\
\hline DW24 & 795 & 686 & 6.5 & 6.7 & 30.4 & 30.5 \\
\hline DW25 & 764 & 837 & 6.7 & 6.6 & 29.4 & 29.6 \\
\hline DW26 & 662 & 526 & 6.7 & 6.7 & 29.0 & 29.7 \\
\hline DW27 & 966 & 673 & 6.5 & 6.9 & 28.2 & 29.8 \\
\hline DW28 & 705 & 426 & 6.6 & 6.8 & 30.6 & 30.0 \\
\hline DW29 & 780 & 555 & 6.6 & 6.9 & 28.5 & 29.7 \\
\hline DW30 & 1105 & 923 & 6.7 & 6.9 & 28.9 & 30.2 \\
\hline DW31 & 1033 & 816 & 6.9 & 8.2 & 30.7 & 30.5 \\
\hline DW32 & 588 & 616 & 6.7 & 6.6 & 28.8 & 29.4 \\
\hline DW33 & 708 & 776 & 6.9 & 7.0 & 30.1 & 29.7 \\
\hline DW34 & 767 & 595 & 6.9 & 7.1 & 28.9 & 29.3 \\
\hline DW35 & 1180 & 1068 & 6.6 & 6.9 & 28.3 & 29.9 \\
\hline DW36 & 815 & 906 & 6.7 & 6.9 & 28.4 & 29.4 \\
\hline BG1 & 593 & 348 & 7.3 & 7.3 & 22.2 & 29.8 \\
\hline BG2 & 589 & 179 & 7.4 & 7.3 & 22.1 & 29.8 \\
\hline BG3 & 618 & .175 .3 & 7.1 & 7.5 & 22.3 & 29.8 \\
\hline BG4 & 580 & 194 & 7.4 & 7.4 & 22.2 & 30.0 \\
\hline
\end{tabular}

Note: DW, BG, DP and WP stand for Dug Well, Buriganga, Dry Period and Wet Period, respectively. 
Table 2. Major ions concentrations $(\mathrm{mg} / \mathrm{L})$ of dug well and Buriganga river water during dry and wet period.

\begin{tabular}{|c|c|c|c|c|c|c|c|c|c|c|}
\hline \multirow{2}{*}{$\begin{array}{c}\text { Sample } \\
\text { ID }\end{array}$} & \multicolumn{2}{|c|}{$\mathrm{Na}$} & \multicolumn{2}{|c|}{$\mathrm{K}$} & \multicolumn{2}{|c|}{$\mathrm{Mg}$} & \multicolumn{2}{|c|}{$\mathrm{Cl}$} & \multicolumn{2}{|c|}{$\mathrm{SO}_{4}$} \\
\hline & DP & WP & DP & WP & DP & WP & DP & WP & DP & WP \\
\hline DW1 & 40.7 & 44.6 & 17.0 & 20.5 & 23.8 & 23.5 & 66.6 & 75.4 & 5.5 & 10.7 \\
\hline $\mathrm{DW}_{2}$ & 42.1 & 46.4 & 10.5 & 11.6 & 21.2 & 24.7 & 57.7 & 66.6 & 2.9 & 2.0 \\
\hline DW3 & 63.5 & 55.5 & 17.6 & 15.4 & 29.4 & 23.1 & 159.8 & 97.6 & 1.7 & 7.4 \\
\hline DW4 & 40.3 & 44.2 & 19.2 & 21.1 & 23.7 & 25.8 & 93.2 & 97.6 & 2.5 & 7.8 \\
\hline DW5 & 47.8 & 48.3 & 21.6 & 21.9 & 27.8 & 25.7 & 119.8 & 48.8 & 1.8 & 2.8 \\
\hline DW6 & 38.2 & 39.0 & 18.6 & 19.5 & 17.3 & 20.5 & 66.6 & 26.6 & 1.7 & 1.6 \\
\hline DW7 & 47.1 & 47.8 & 21.4 & 23.7 & 17.6 & 21.2 & 93.2 & 53.3 & 1.5 & 2.5 \\
\hline DW8 & 29.8 & 30.7 & 4.6 & 5.4 & 15.1 & 19.1 & 57.7 & 48.8 & 2.0 & 3.3 \\
\hline Dw9 & 29.6 & 30.2 & 6.9 & 7.0 & 14.2 & 18.4 & 48.8 & 26.6 & 1.4 & 1.7 \\
\hline DW10 & 45.8 & 26.1 & 13.5 & 7.6 & 18.6 & 17.9 & 75.4 & 26.6 & 2.0 & 3.7 \\
\hline DW11 & 46.2 & 38.2 & 10.7 & 9.7 & 16.6 & 19.8 & 84.3 & 26.6 & 7.2 & 2.9 \\
\hline DW12 & 52.7 & 36.9 & 19.2 & 13.5 & 22.6 & 18.0 & 102.1 & 26.6 & 3.3 & 9.5 \\
\hline DW13 & 32.7 & 33.2 & 11.4 & 11.6 & 15.0 & 18.5 & 48.8 & 22.2 & 4.4 & 5.3 \\
\hline DW14 & 31.9 & 31.0 & 10.2 & 10.2 & 15.6 & 18.9 & 53.3 & 13.3 & 4.0 & 5.6 \\
\hline DW15 & 58.4 & 46.4 & 12.7 & 11.2 & 20.9 & 20.1 & 97.6 & 22.2 & 1.6 & 3.0 \\
\hline DW16 & 36.4 & 40.3 & 12.7 & 16.5 & 15.6 & 18.5 & 66.6 & 26.6 & 1.5 & 2.0 \\
\hline DW17 & 52.1 & 44.7 & 14.7 & 13.7 & 20.2 & 19.5 & 97.6 & 26.6 & 1.4 & 2.3 \\
\hline DW18 & 40.3 & 38.9 & 14.7 & 13.0 & 18.4 & 18.6 & 84.3 & 26.6 & 2.0 & 1.8 \\
\hline DW19 & 55.9 & 41.4 & 17.4 & 14.9 & 21.5 & 20.2 & 124.3 & 31.1 & 2.5 & 2.4 \\
\hline DW20 & 45.6 & 41.2 & 11.7 & 11.6 & 21.8 & 21.9 & 124.3 & 26.6 & 3.2 & 4.3 \\
\hline DW21 & 51.9 & 29.6 & 14.9 & 9.3 & 2.3 & 19.1 & 115.4 & 26.6 & 1.8 & 2.7 \\
\hline DW22 & 65.4 & 48.2 & 19.2 & 18.6 & 23.4 & 19.2 & 177.5 & 31.1 & 2.5 & 3.2 \\
\hline DW23 & 63.7 & 48.2 & 18.4 & 17.9 & 23.8 & 19.4 & 124.3 & 31.1 & 1.5 & 3.7 \\
\hline DW24 & 52.8 & 40.6 & 13.8 & 14.9 & 21.7 & 20.5 & 115.4 & 22.2 & 9.0 & 2.7 \\
\hline DW25 & 53.2 & 57.3 & 13.6 & 16.7 & 20.5 & 21.0 & 115.4 & 26.6 & 18.2 & 3.8 \\
\hline DW26 & 43.3 & 29.9 & 8.3 & 7.7 & 18.0 & 21.4 & 84.3 & 31.1 & 13.2 & 2.9 \\
\hline DW27 & 67.0 & 43.6 & 26.2 & 22.5 & 26.0 & 19.8 & 142 & 35.5 & 13.0 & 12.3 \\
\hline DW28 & 69.2 & 26.2 & 8.7 & 7.6 & 20.9 & 18.6 & 124.3 & 35.5 & 11.5 & 9.3 \\
\hline DW29 & 64.6 & 38.4 & 13.5 & 12.5 & 20.3 & 18.3 & 195.3 & 31.1 & 14.5 & 10.7 \\
\hline DW30 & 80.2 & 53.9 & 24.6 & 23.2 & 26.8 & 21.5 & 213 & 35.5 & 7.8 & 9.0 \\
\hline DW31 & 87.2 & 52.3 & 23.0 & 22.1 & 5.1 & 20.4 & 248.5 & 35.5 & 11.2 & 7.4 \\
\hline DW32 & 34.2 & 32.8 & 6.9 & 7.0 & 24.7 & 24.8 & 102.1 & 26.6 & 5.1 & 6.4 \\
\hline DW33 & 68.0 & 50.4 & 8.2 & 12.1 & 21.3 & 23.9 & 102.1 & 57.7 & 17.5 & 6.5 \\
\hline DW34 & 65.2 & 37.4 & 12.3 & 11.2 & 21.6 & 20.5 & 119.8 & 53.3 & 12.5 & 8.8 \\
\hline DW35 & 79.2 & 65.0 & 25.8 & 24.6 & 35.7 & 27.6 & 221.9 & 44.4 & 12.4 & 6.8 \\
\hline DW36 & 47.1 & 44.1 & 16.5 & 19.8 & 26.0 & 17.7 & 110.9 & 44.4 & 13.2 & 7.3 \\
\hline BGI & 100.8 & 100.8 & 3.8 & 3.2 & 19.8 & 14.6 & 39.9 & 26.6 & 15.9 & 5.8 \\
\hline $\mathrm{BG2}$ & 97.2 & 15.8 & 3.7 & 3.0 & 19.6 & 14.4 & 35.5 & 35.5 & 17.3 & 6.6 \\
\hline BG3 & 943 & 15.5 & 6.3 & 2.8 & 51.9 & 14.9 & 31.1 & 35.5 & 21.0 & 6.1 \\
\hline BG4 & 99.1 & 15.1 & 3.2 & 3.0 & 21.2 & 15.0 & 35.5 & 22.2 & 16.9 & 6.0 \\
\hline
\end{tabular}




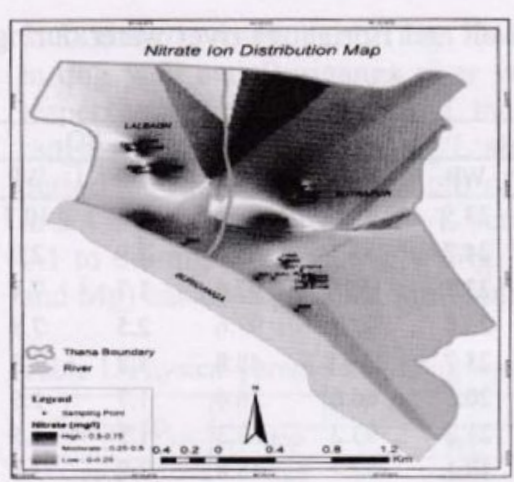

(a) Dry Period (DW-Max. $0.8 \mathrm{mg} / \mathrm{L}$, Min. 0 $\mathrm{mg} / \mathrm{L} ;$ BG- Max. $0.3 \mathrm{mg} / \mathrm{L}$, Min. $0 \mathrm{mg} / \mathrm{L}$ )

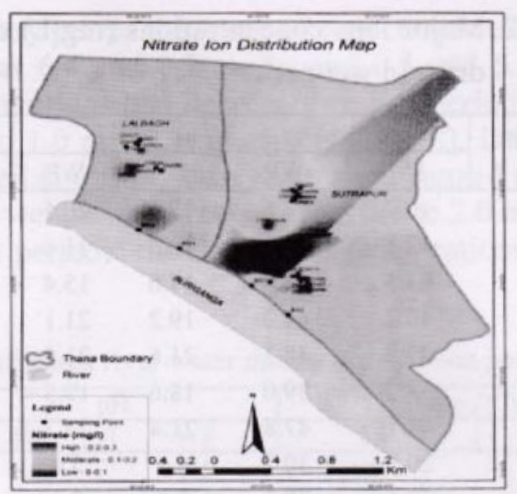

(b) Wet Period (DW- Max. $0.3 \mathrm{mg} / \mathrm{L}$, Min. $0 \mathrm{mg} / \mathrm{L}$; BG- Max. $0.1 \mathrm{mg} / \mathrm{L}$, Min. $0 \mathrm{mg} / \mathrm{L}$ )

Fig. 6. $\mathrm{NO}_{3}$ ion concentration distribution maps of DW and $\mathrm{BG}$ water in the study area during dry (a) and wet (b) period.

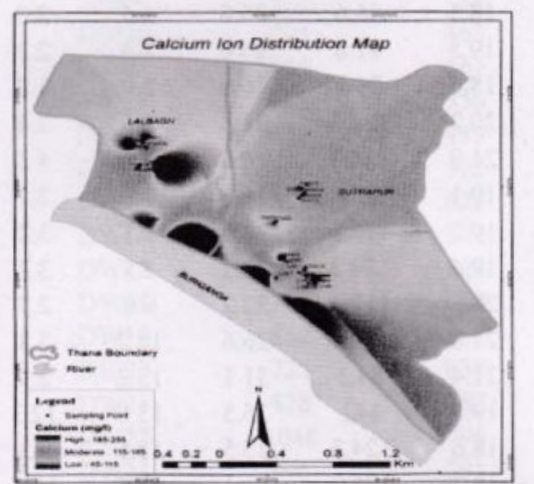

(a) Dry Period (DW-Max. $251.1 \mathrm{mg} / \mathrm{L}$, Min. 23 $\mathrm{mg} / \mathrm{L}$; BG- Max. $188.5 \mathrm{mg} / \mathrm{L}$, Min. $47.6 \mathrm{mg} / \mathrm{L}$ )

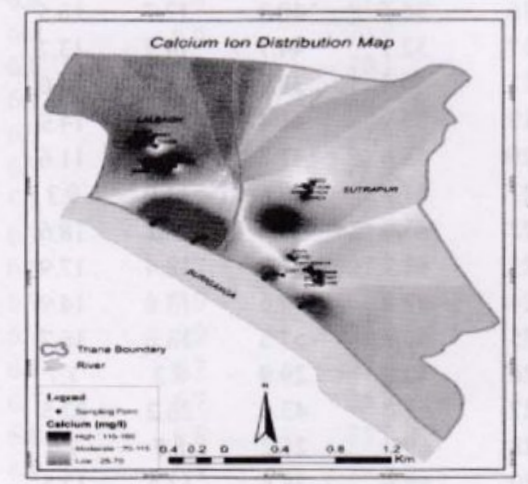

(b) Wet Period (DW- Max. $151.8 \mathrm{mg} / \mathrm{L}$, Min. 63.1 mg/L; BG- Max. 38.6 mg/L, Min. 30.1 mg/L)

Fig. 7. Maps showing the distribution of Ca ion concentration of DW and BG water of the study area during dry (a) and wet (b) period.

Hydrochemical Facies: After plotting the water sample data in the Piper diagram, it was found that $\mathrm{Ca}$ remained as the dominant cation during both dry and wet period and same was the case with the $\mathrm{HCO}_{3}$ anion (Piper 1953). Results of hydrochemical facies analyses show that both the dug well and Buriganga river water are of $\mathrm{Ca}-\mathrm{HCO}_{3}$ type. It was also found that both the dry and wet period water give the same result (Figs. 10 and 11). 


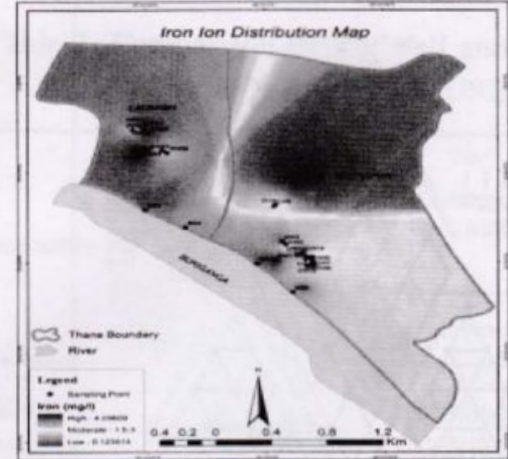

(a) Dry Period (DW- Max. $6.4 \mathrm{mg} / \mathrm{L}$, Min. 0.2 $\mathrm{mg} / \mathrm{L}$; BG- Max. $5.0 \mathrm{mg} / \mathrm{L}$, Min. $0.5 \mathrm{mg} / \mathrm{L}$ )

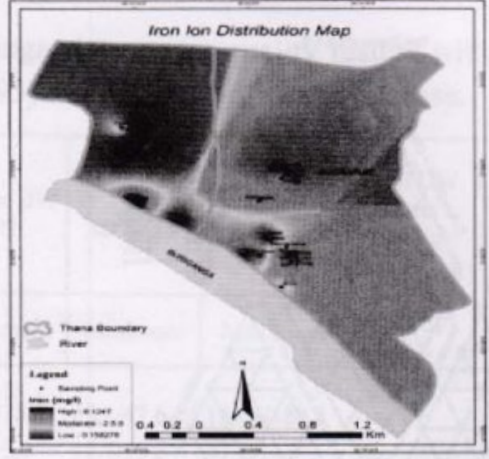

(b) Wet Period (DW- Max. $4.6 \mathrm{mg} / \mathrm{L}$, Min. $0.1 \mathrm{mg} /$; BG- Max. $1.0 \mathrm{mg} / \mathrm{L}$, Min. $0.5 \mathrm{mg} / \mathrm{L}$ )

Fig. 8. Maps showing the distribution of Fe ion concentration of DW and BG water of the study area during dry (a) and wet (b) period.

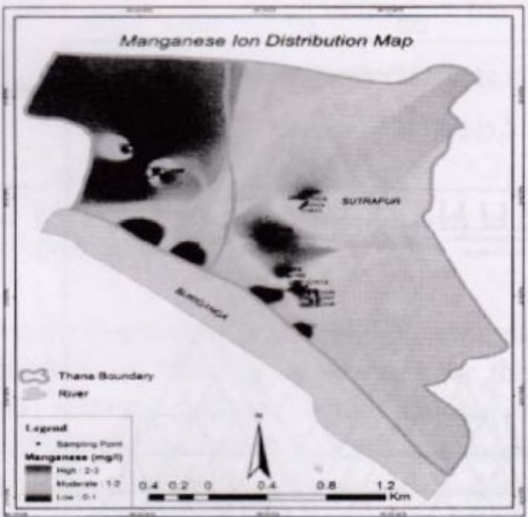

(a) Dry Period (DW- Max. $2.4 \mathrm{mg} / \mathrm{L}$, Min. $0.1 \mathrm{mg} / \mathrm{L}$; BG- Max. $2.1 \mathrm{mg} / \mathrm{L}$, Min. $0.3 \mathrm{mg} / \mathrm{L}$ )

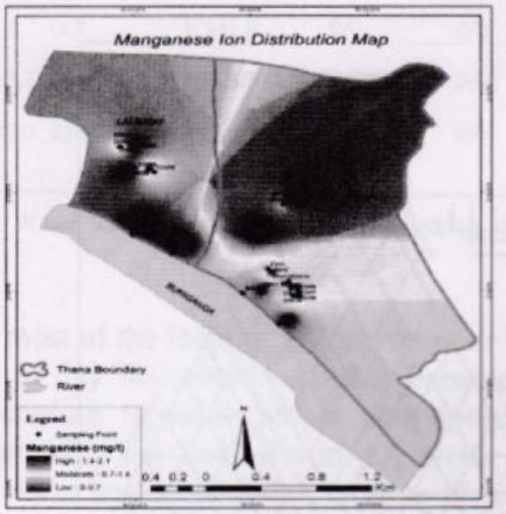

(b) Wet Period (DW- Max. $2.0 \mathrm{mg} / \mathrm{L}$, Min. 0.1 $\mathrm{mg} / \mathrm{L}$; BG- Max. $0.6 \mathrm{mg} / \mathrm{L}$, Min. $0.1 \mathrm{mg} / \mathrm{L}$ )

Fig. 9. Maps showing the distribution of Mn ion concentration of DW and BG water of the study area during dry (a) and wet (b) period.

Water Quality: Drinking water quality requires high physical and chemical purity. It should be free from undesirable physical properties, cloudiness and objectionable odor and taste. Analytical results of the thirty six dug well and four Buriganga river water samples of the study area had been evaluated and compared with various drinking water quality parameters following the guidelines of World Health Organization (WHO 2004), Department of Environment, Bangladesh (DOE 1997) and United States Environmental Protection Agency (USEPA 1995) (Table 3). The study shows that, in case of $\mathrm{Ca}, \mathrm{K}$ and 


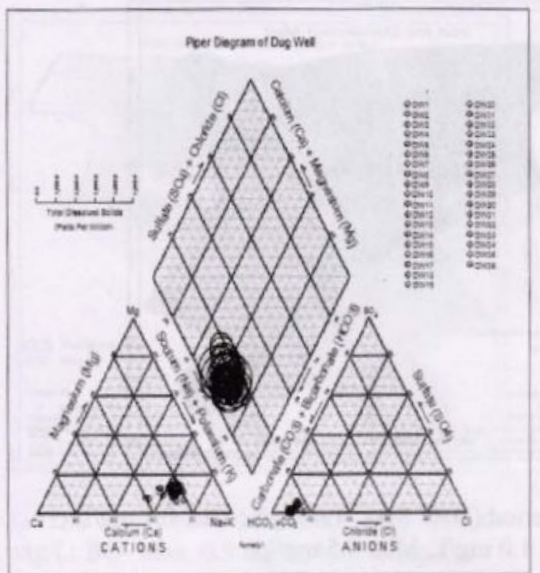

(a)

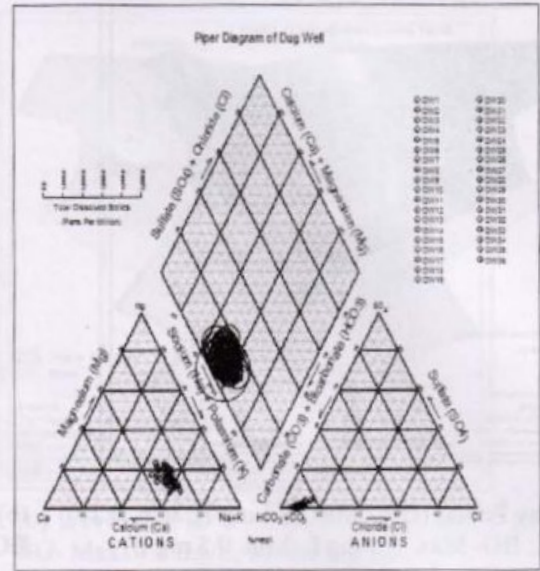

(b)

Fig. 10. Hydrochemical classification of dug well water during dry (a) and wet (b) period.

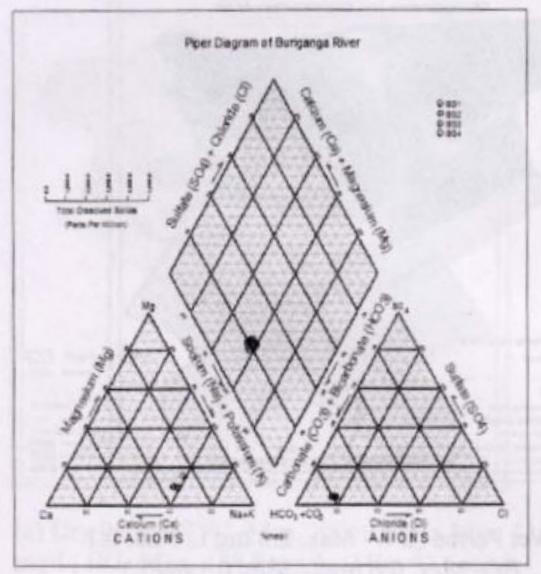

(a)

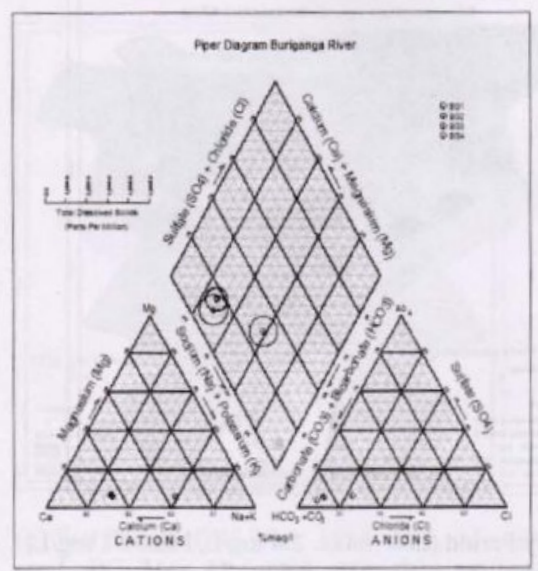

(b)

Fig. 11. Hydrochemical classification of Buriganga river water during dry (a) and wet (b) period.

Fe ions, more than $50 \%$ dug well water samples exceeded the drinking water quality standard limits during dry and wet periods. On the other hand, in case of $\mathrm{Ca}, \mathrm{Mg}$ and $\mathrm{Mn}$ ions, $25 \%$ Buriganga river water samples exceeded the drinking water quality standard limits during dry period; Mn shows the same result during wet period; in addition to that, in case of $\mathrm{Fe}$ ion concentration, $50 \%$ samples exceeded the acceptable standard limits during dry period. As far as the hardness of the waters is concerned, $33 \%$ dug well water and $25 \%$ river water exceeded the standard limits during dry period (Table 3 ). 
Table 3. Comparison of dug well and Buriganga river water quality results with WHO (2004), DOE (1997) and USEPA (1995) standards for drinking purpose.

\begin{tabular}{|c|c|c|c|c|c|c|c|c|c|}
\hline \multirow{2}{*}{ Parameters } & \multirow{2}{*}{\begin{tabular}{|l|}
$\begin{array}{c}\text { WHO } \\
(2004)\end{array}$ \\
$\begin{array}{l}\text { DWRL } \\
(\mathrm{mg} / \mathrm{L})\end{array}$ \\
\end{tabular}} & \multirow{2}{*}{\begin{tabular}{|c|}
$\begin{array}{c}\text { DOE } \\
(1997)\end{array}$ \\
$\begin{array}{l}\text { DWRL } \\
(\mathrm{mg} / \mathrm{L})\end{array}$ \\
\end{tabular}} & \multirow{2}{*}{\begin{tabular}{|c|}
$\begin{array}{c}\text { USEPA } \\
(1995)\end{array}$ \\
$\begin{array}{l}\text { DWRL } \\
(\mathrm{mg} / \mathrm{L})\end{array}$ \\
\end{tabular}} & \multicolumn{2}{|c|}{$\begin{array}{c}\text { Obtained results for DW } \\
\text { water (DP/WP) }\end{array}$} & \multicolumn{2}{|c|}{$\begin{array}{l}\text { Obtained results } \\
\text { for BG River (DP/WP) }\end{array}$} & \multirow{2}{*}{$\begin{array}{c}\% \text { of DW } \\
\text { water } \\
\text { samples } \\
\text { exceeding } \\
\text { DWQSL } \\
\text { (DP/WP) }\end{array}$} & \multirow{2}{*}{$\begin{array}{c}\% \text { of BG } \\
\text { River } \\
\text { water } \\
\text { samples } \\
\text { exceeding } \\
\text { DWQSL } \\
\text { (DP/WP) }\end{array}$} \\
\hline & & & & Minimum & Maximum & Minimum & Maximum & & \\
\hline Calcium & - & 75 & - & $91.9 / 30.1$ & $251.1 / 38.6$ & $63.1 / 47.6$ & $151.8 / 188.5$ & $100 / 75$ & $25 / 0$ \\
\hline Magnesium & - & $30-35$ & $\cdot$ & $14.2 / 14.3$ & $35.7 / 15.0$ & $17.7 / 19.6$ & $27.6 / 51.9$ & $3 / 0$ & $25 / 0$ \\
\hline Sodium & 200 & 200 & - & $29.6 / 15.1$ & $87.2 / 16.0$ & $26.1 / 94.3$ & $65 / 100.8$ & $0 / 0$ & $0 / 0$ \\
\hline Potassium & - & 12 & - & $4.6 / 2.8$ & $26.2 / 3.2$ & $5.4 / 5.6$ & $24.6 / 10.9$ & $70 / 61$ & $0 / 0$ \\
\hline Iron & 0.3 & $0.3 \cdot 1.0$ & 0.3 & $0.2 / 0.5$ & $6.4 / 1.0$ & $0.1 / 0.5$ & $4.6 / 5.0$ & $67 / 58$ & $50 / 0$ \\
\hline Manganese & 0.1 & 0.5 & - & $0.1 / 0.1$ & $2.4 / 2.0$ & $0.2 / 0.1$ & $0.3 / 0.6$ & $27 / 26$ & $25 / 25$ \\
\hline Bicarbonate & - & - & - & $213.5 / 114.4$ & $518.5 / 137.3$ & $228.8 / 274.5$ & $1052.3 / 449.9$ & $0 / 0$ & $0 / 0$ \\
\hline Chloride & 250 & $150-600$ & 250 & $48.8 / 22.2$ & $248.5 / 35.5$ & $13.3 / 31.1$ & $97.6 / 39.9$ & $0 / 0$ & $0 / 0$ \\
\hline Nitrate & 10 & 15 & 10 & $0 / 0$ & $0.8 / 0.1$ & $0 / 0$ & $0.3 / 0.1$ & $0 / 0$ & $0 / 0$ \\
\hline $\begin{array}{l}\text { Total } \\
\text { Hardness }\end{array}$ & $\cdot$ & $200-500$ & $200-500$ & $287.7 / 134.1$ & $774.3 / 157.7$ & $234 / 199.2$ & $492.5 / 684.2$ & $33 / 0$ & $25 / 0$ \\
\hline TDS & 1500 & 1000 & $\cdot$ & $301.0 / 105.2$ & $733.0 / 209.0$ & $256.0 / 348.0$ & $641.0 / 371.0$ & $0 / 0$ & $0 / 0$ \\
\hline
\end{tabular}

Note: DWRL and DWQSL refer respectively to Drinking Water Recommended Limit and Drinking Water Quality Standard Limits.

From the present study it may be concluded that most of the local people are more or less dependent on the dug well water for their day to day household activities because of water scarcity mainly during dry period. According to local people anthropogenic activities and sewerage leakage are mainly responsible for bad odor in dug wells and Buriganga river during dry period, and this appears to be dark in color, but this situation becomes reversed during wet period. Local people use Calcium carbonate $\left(\mathrm{CaCO}_{3}\right)$ and bleaching powder $[\mathrm{Ca}(\mathrm{OCl}) \mathrm{Cl}]$ to clean-up water; plastering is also employed to avoid the caving in and also to keep the wall dry and free from algae. As far as the physical parameters, chemical analyses, spatial distribution maps and hydrochemical facies analyses are concerned, the results presented here give the impression that the physical and chemical parameters of dug well and Buriganga river water are almost identical. Over $50 \%$ dug well and $25 \%$ Buriganga river water samples exceed drinking water quality standard limits of WHO (2004), DOE (1997) and USEPA (1995). It has not been deciphered yet the source of contamination as well as recharge to dug wells. Thus, the present study leads to the recommendation that comprehensive initiatives are indispensable for monitoring and proper maintaining these historic dug wells in Old Dhaka of the capital city for investigating the cause of contamination and source of recharge to dug wells. 


\section{References}

Ahmed, K. M., M. S. Islam and S. Sultana. 2011. Changes in the Groundwater Regime of Dhaka City:A Historical Perspective, pp. 383-400. In M. Anwarul Islam (ed.) Environment of Capital Dhaka-Plants Wildlife Gardens Parks Air Water Earthquake. Asiatic Society of Bangladesh, Dhaka. pp. 383-400.

DOE. 1997. Bangladesh Gazette. Ministry of Environment and Forest. GOB. DA-1. pp. 3124-4134.

D'Souza, R. 2006. Water in British India: The Making of a 'Colonial Hydrology'. History Compass, 4/4: pp. 621-628, 10.1111/j.1478-0542.2006.00336.

Jackson, M.L. 1967. Soil Chemical Analysis. Prentice Hall Inc. Englewood Cliffs. NJ. USA. pp 227-267.

Khan, A.Q. and J. L. Stockard. 1968. An outbreak of Cholera in a Dacca City Household. Journal of the Pakistan Medical Association, 18(7): pp. 268-272.

Miah, M.M. and B.I. Bazlee. 1968. Some aspect of the Geomorphology of the Madhupur Tract, Oriental Geographer, Dhaka. pp. 39-48.

Michael, A.M. 1992. Irrigation Theory and Practices. Vikas Publishing House Ltd., New Delhi, pp. 740.

Misra, R.D. and M. Ahmed. 1987. Manual on Irrigation Agronomy. Oxford and IBH Publishing Co. Pvt. Ltd., New Delhi. pp. 248-271.

Monsur, M.H. 1995. An Introduction to the Quaternary Geology of Bangladesh. A Complementary Research of IGCP347. Quaternary Stratigraphic Correlation of the Ganges Brahmaputra Sediments, Dhaka, pp. 19.

Page, A.L. 1982. Methods of soil analysis (ed). Part 2 Am. Soc. Agron-Soil Sci. Am. Madison, Wis. USA. pp. 159-446.

Piper, A. M. 1953. A graphic procedure in the geochemical interpretation of water analysis, USGS Groundwater note No. 12. pp. 13.

Taylor, J. 1840. A sketch of the Topography and statistics of Dacca. Huffmann, Military Orphan Press, Calcutta. pp. 284.

USEPA, 1995. Quality criteria for water. Washington, D.C. pp. 501.

WHO, 2004. Guidelines For Drinking Water Quality. 3rd ed, Vol. 1, Recommendations, World Health Organization, Geneva. pp. 515. 